\title{
Influence of oxytocin removal from the corpus luteum on secretory function and duration of the oestrous cycle in cattle
}

\author{
J. Kotwica and D. Skarzynski \\ Division of Animal Reproduction Endocrinology and Pathophysiology, Centre for Agrotechnology and \\ Veterinary Sciences, Polish Academy of Sciences, 10-718 Olsztyn-Kortowo, PO Box 55, Poland
}

\begin{abstract}
Mature heifers ( $n=31$ ) were infused with either saline or noradrenaline $\left(0.3 \mu \mathrm{g} \mathrm{kg}^{-1} \mathrm{~min}^{-1}\right)$ via a cannula inserted into the aorta abdominalis through the coccygeal artery (cranial to the origin of the ovarian artery). Noradrenaline was infused for three periods of $30 \mathrm{~min}$ on days 11 and 12 and on days 15 and 16 of the oestrous cycle. After the noradrenaline treatment, saline was given for $1 \mathrm{~h}$ in the same way. During each infusion, peripheral blood samples were collected for progesterone and oxytocin determination every 5-10 $\mathrm{min}$ and then once a day until oestrus. As a control, four heifers were infused with saline in latin square design on days 11,12 and on days 15, 16; they were bled once a day until oestrus. Other heifers were infused on the same days, but $1 \mathrm{~h}$ after the last infusion of noradrenaline, $500 \mu \mathrm{g}$ of prostaglandin $\mathrm{F}_{2 \alpha}\left(\mathrm{PGF}_{2 \alpha}\right)$ analogue was injected, to measure any remaining luteal oxytocin. For comparison four heifers were injected with $\mathrm{PGF}_{2 \alpha}$ analogue alone on day 12 and four others on day 16. Blood samples were taken as described previously. Each infusion of noradrenaline stimulated $(P<0.01)$ progesterone secretion. There was a significant $(P<0.05)$ response of oxytocin to each noradrenaline stimulation on days 11 and 12 , although on each day the response to the second infusion was reduced and further reduced after the third infusion. On days 15 and 16, only the first noradrenaline infusion caused a clear surge of oxytocin with much smaller increases in oxytocin secretion after subsequent infusions. Noradrenaline stimulation reduced the total content of oxytocin in the corpus luteum on day 12 by $68-82 \%$ (mean $73.3 \%$ ) and by $74 \%$ on day 16 . The duration of the oestrous cycle was $20.8 \pm 0.6$ and $21.0 \pm 0.4$ days, respectively, in heifers infused with noradrenaline compared with $21.0 \pm 0.5$ days in controls. Noradrenaline infusions markedly reduced the total amount of oxytocin in mid- and late-cycle bovine corpora lutea but this did not affect either spontaneous luteolysis or the duration of the oestrous cycle. It is therefore assumed that ovarian oxytocin may have a permissive role rather than a direct action on luteolysis in cattle.
\end{abstract}

\section{Introduction}

Ovarian oxytocin has been suggested as a trigger for the pulsatile secretion of prostaglandin $F_{2 \alpha}\left(\mathrm{PGF}_{2 \alpha}\right)$ in ewes (McCracken et al., 1984; Flint and Sheldrick, 1986). A physiological role during luteolysis in cattle is, however, still obscure and controversial (Pickering et al., 1990). There are data supporting the view that oxytocin is important during luteolysis (Gross et al., 1988; Lafrance and Goff, 1988; Silvia and Taylor, 1989), but the bovine endometrium is sensitive to oxytocin challenge only during the periovulatory period and not during the luteal phase (Kotwica et al., 1987; Lafrance and Goff, 1990; Del Vecchio et al., 1991). Furthermore the highest concentration of oxytocin in the bovine corpus luteum occurs in the mid-luteal phase and the concentration is very low at the time of luteolysis (Wathes et al., 1984; Fehr et al., 1987; Fuchs,

Received 2 April 1992.
1988). An experiment designed to remove oxytocin from the corpus luteum would indicate any possible physiological significance. Until recently $\mathrm{PGF}_{2 \alpha}$ and its analogues were the only factors known to deplete the corpus luteum of oxytocin (Flint and Sheldrick, 1982); but PGF $_{2 \alpha}$ causes luteolysis, so the effect of the absence of oxytocin on corpus luteum function would not be observed in such studies. It is now known that noradrenaline also causes the release of ovarian oxytocin in heifers with an efficiency comparable to that of $\mathrm{PGF}_{2 \alpha}$ (Kotwica et al., 1991a); but, contrary to the action of $\mathrm{PGF}_{2 \alpha^{\prime}}$ noradrenaline also enhances the secretion of progesterone and this effect is observed in conscious animals within a few minutes of application of noradrenaline (Kotwica et al., 1991a). The oxytocin prohormone is synthesized in the ovary only during the first few days of the oestrous cycle (Ivell et al., 1985; Fehr et al., 1987) and once depleted cannot be replaced (Ivell, 1987). Noradrenaline can be used to deplete the bovine corpus luteum of oxytocin to determine its physiological function. 


\section{Materials and Methods}

\section{Animals and surgery}

Thirty-one mature heifers $(380-450 \mathrm{~kg})$ with regular ovarian cyclicity (18-22 days) were used in this study. The day of onset of heat was designated day 0 of the oestrous cycle. One day before the study, a polyvinyl chloride catheter was inserted into the abdominal aorta through the coccygeal artery (Kotwica et al., 1990) for the infusion of either saline or noradrenaline $\left(0.3 \mu \mathrm{g} \mathrm{kg}^{-1} \mathrm{~min}^{-1}\right)$. The tip of each cannula was positioned cranial to the origin of the ovarian artery to allow direct application of drugs to the reproductive tract; this permitted the use of a lower dose of noradrenaline and hence avoided side effects.

\section{Experiment 1}

On day 11 of the oestrous cycle, noradrenaline was infused three times for $30 \mathrm{~min}$ in four heifers. After each noradrenaline treatment saline was given for $1 \mathrm{~h}$ in the same way. On day 12 noradrenaline was infused in the same manner and $1 \mathrm{~h}$ after the last infusion of drug, a luteolytic dose $(500 \mu \mathrm{g})$ of $\mathrm{PGF}_{2 \alpha}$ analogue (Oestrophan: Spofa, Czechoslovakia) was injected, to measure any remaining luteal oxytocin. Control heifers $(n=4)$ in this experiment were infused with saline only on days II and 12 of the oestrous cycle in the same way. PGF $_{2 \alpha}$ was then injected to measure any oxytocin remaining in the corpora lutea, assuming that $\mathrm{PGF}_{2 a}$ removes approximately $98 \%$ of ovarian oxytocin (Flint and Sheldrick, 1983). During infusion of noradrenaline and for $30 \mathrm{~min}$ after $\mathrm{PGF}_{2 a}$ injection, blood samples were collected via a catheter inserted into the jugular vein every $5 \mathrm{~min}$, and every $10 \mathrm{~min}$ in between infusions.

\section{Experiment 2}

Noradrenaline was infused on days 11 and 12 of the cycle in heifers $(n=5)$ and blood samples were collected as described in Expt 1 . Blood samples were then taken once a day until day 23 of the cycle when symptoms of heat were observed.

\section{Experiment 3}

Heifers $(n=4)$ were infused with noradrenaline on days 15 and 16 of the cycle (just before luteolysis was anticipated) as described in Expt 1. After the last infusion of drug on day 16, a luteolytic dose of $\mathrm{PGF}_{2 \alpha}$ analogue was injected as in Expt 1. Control heifers $(n=4)$ in this experiment were infused with saline instead of noradrenaline and on day 16 they were injected with $\mathrm{PGF}_{2 \alpha}$ analogue to measure the concentration of oxytocin in the corpus luteum in the absence of pretreatment with noradrenaline.

\section{Experiment 4}

Noradrenaline was infused on days 15 and 16 of the cycle in six heifers as in the previous experiments. Frequency of blood sampling during the infusions and thereafter, until day 23 of the cycle, was the same as in Expt 2. As a control for heifers in Expts 2 and 4, four heifers were infused with saline in latin square design on days 11,12 and 15,16 and blood samples were collected once a day until onset of oestrus.

Clotting of blood samples $(8 \mathrm{ml})$ taken from the jugular vein was prevented by the addition of $30 \mu \mathrm{mol}$ EDTA $\mathrm{l}^{-1}$ and $1 \%$ aspirin to the sample (Meyer et al., 1989). Samples were then chilled in an ice-bath for at least $10 \mathrm{~min}$, centrifuged $(800 \mathrm{~g}$ for $10 \mathrm{~min}$ at $4^{\circ} \mathrm{C}$ ) and plasma was stored at $-18^{\circ} \mathrm{C}$.

\section{Hormone analysis}

Oxytocin and progesterone concentrations were determined as described by Schams et al. (1979) and Kotwica et al. (1990), respectively. Anti-ovine progesterone antiserum (GDN No. 337; donated by G. D. Niswender, Colorado) used in this assay was characterized by Gibori et al. (1977), whereas anti-rabbit oxytocin antiserum (R-1; donated by G. Kotwica) showed less than $0.01 \%$ crossreactivity with arginine-vasopressin, lysinevasopressin, angiotensin, vasotocin and somatostatin (Sigma, Germany). Sensitivity of the assay averaged $0.3-0.6 \mathrm{ng} \mathrm{m}^{-1}$ for progesterone and $3 \mathrm{pg} \mathrm{ml}^{-1}$ for oxytocin. Coefficients of correlation between added and recovered amounts of progesterone and oxytocin in plasma for four different concentrations were 93 and $95 \%$, respectively. Intra- and interassay coefficients of variation were 9.6 and $20.2 \%$ for progesterone and 5.6 and $10.5 \%$ for oxytocin, respectively.

Plasma concentrations of 13,14-dihydro-15-keto-prostaglandin $\mathrm{F}_{2 \alpha}$ (PGFM) in blood samples from heifers infused with noradrenaline on days 15 and 16 were determined by a direct radioimmunoassay described by Homanics and Silvia (1988). The antiserum (WS4468 BD 6/23-7/21) and free and antibody-bound tracer were separated by charcoal precipitation. Sensitivity of the assay was $90 \mathrm{pg} \mathrm{ml}^{-1}$, and the intra- and interassay coefficients of variation were 6.8 and $11.3 \%$, respectively.

\section{Statistical analysis}

Mean basal concentrations from time -60 to 0 min were subtracted from all values and the area under the curve for oxytocin and progesterone during each noradrenaline infusion and for $30 \mathrm{~min}$ after treatment with $\mathrm{PGF}_{2 \alpha}$ analogue were calculated and compared. The total amount of oxytocin released from the corpus luteum during Expts 1 and 3 was measured by calculating the area under the curve and this was compared with that for heifers treated with $\mathrm{PGF}_{2 \alpha}$ alone. Differences between mean values were estimated by one-way analysis of variance. The time of the significant increase of oxytocin after the start of treatment was also estimated. Pearson's coefficient of correlation between progesterone and oxytocin during treatment was calculated.

\section{Results}

\section{Experiment 1}

Within $5 \mathrm{~min}$ of the start of the noradrenaline infusion, a sharp increase in oxytocin concentration was observed $(P<0.01)$; during infusion, it was highly correlated with the increase in progesterone concentration $(r=0.33-0.68$; 


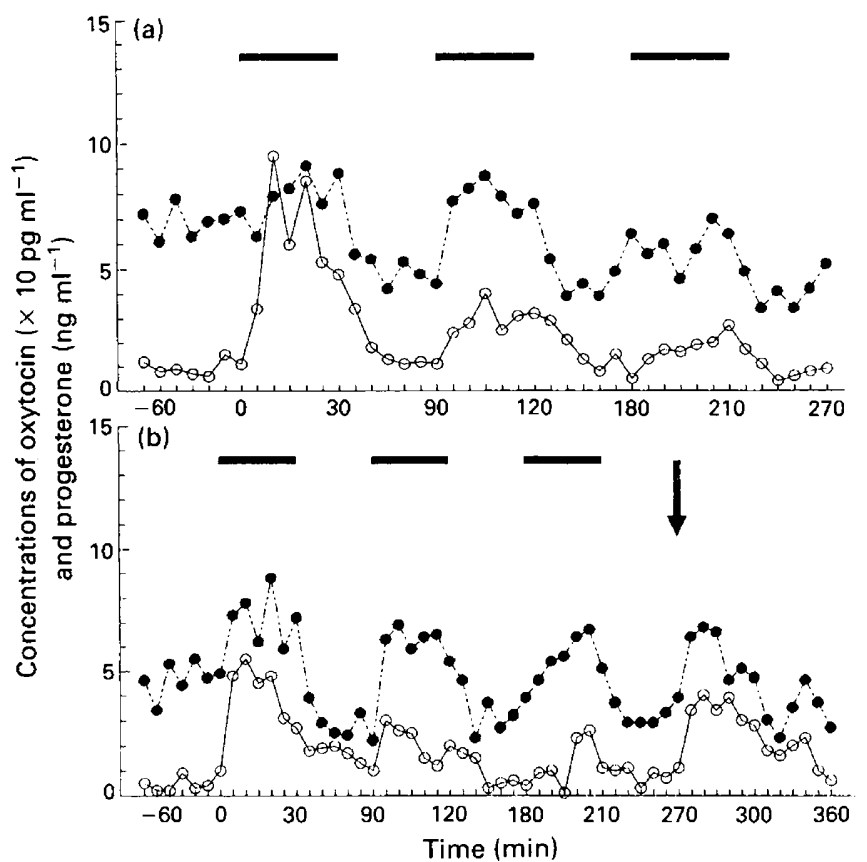

Fig. 1. Peripheral plasma concentrations of $(O)$ oxytocin and $(O)$ progesterone from one representative heifer infused with noradrenaline $\left(0.3 \mu \mathrm{g} \mathrm{kg}^{-1} \mathrm{~min}^{-1}\right)$ three times for $30 \mathrm{~min}(-)$ on (a) day 11 and (b) day 12. One hour after last infusion on day $12,500 \mu \mathrm{g}$ of $\mathrm{PGF}_{2 \alpha}$ analogue was injected (arrow).

$P<0.06-0.001$ ) (Fig. 1). The release of oxytocin after each noradrenaline challenge was significantly lower than the previous one $(P<0.05)$. The total amount of oxytocin released by noradrenaline on day $11(42.3 \pm 1.4 \%)$ was higher $(P<0.06)$ than on day $12(31.2 \pm 1.1 \%)$ of the cycle (Table 1). Nevertheless, $\mathrm{PGF}_{2 \alpha}$ analogue given after the last noradrenaline infusion could still release significant amounts of oxytocin $(26.3 \pm 3.0 \%)$, although the amounts were lower $(P<0.02)$ than those secreted during the noradrenaline infusions on day 11 (Table 1). This amount was only $18-32 \%$ of that released in control heifers (injected with $\mathrm{PGF}_{2 \alpha}$ and not pretreated with noradrenaline) (Fig. 2; Table 1). This means that noradrenaline infusions on day 11 and 12 depleted bovine corpora lutea of approximately $75 \%$ of their oxytocin content (Table 1 ). PGF $_{2 \alpha}$ given after noradrenaline infusions, caused a significantly higher $(P<0.01)$ increase in progesterone secretion than $\mathrm{PGF}_{2 a}$ alone. This rise in progesterone secretion was positively correlated $(r=0.73 ; P<0.001)$ with oxytocin secretion.

\section{Experiment 2}

The pattern of both oxytocin and progesterone secretion during noradrenaline infusion in this experiment was similar to data in Expt 1. However, this did not influence the duration of the oestrous cycle $(20.8 \pm 0.6$ days) compared with the duration of the cycle in control heifers, i.e. $21.0 \pm 0.5$ days (Table 2).

\section{Experiment 3}

The increases in progesterone secretion during each noradrenaline infusion on days 15 and 16 were significant (Fig.
3) and the patterns were comparable to those released on days 11 and 12 (Fig. 1). Oxytocin concentrations after noradrenaline infusions, although significantly increased, were approximately half of those secreted on days 11 and $12 . \mathrm{PGF}_{2 \alpha}$ injection after the last infusion of noradrenaline on day 16 resulted in a lower secretion of oxytocin $(P<0.02)$ compared with that secreted after the noradrenaline infusions on day 15 (Table 1 ) and was only $25 \%$ of that released by $\mathrm{PGF}_{2 \alpha}$ in control heifers. Noradrenaline infusions therefore reduced oxytocin content in the corpus luteum by $75 \%$. It is noteworthy that the amount of oxytocin released by noradrenaline followed by $\mathrm{PGF}_{2 a}$ was almost identical to that released on day 16 by $\mathrm{PGF}_{2 \alpha}$ treatment alone (Table 1). This indicates that our assumption concerning the calculation of oxytocin release by noradrenaline and $\mathrm{PGF}_{2 \alpha}$ is acceptable.

\section{Experiment 4}

The pattern of progesterone secretion during noradrenaline infusion was similar to those in Expts 1 and 2. The profile of oxytocin secretion was, however, markedly different. The response of oxytocin to noradrenaline treatment was clearly observed only during the first infusion. All subsequent noradrenaline infusions stimulated oxytocin release only slightly or there was no release (Fig. 3). The total amount of oxytocin secreted following treatment with noradrenaline and $\mathrm{PGF}_{2 \alpha}$ was almost identical to that secreted when saline followed by $\mathrm{PGF}_{2 \alpha}$ were given (Table 1, Fig. 4). Duration of the oestrous cycle (21.0 \pm 0.4 days) was not changed compared with control heifers (21.0 \pm 0.5 days) (Table 2). Surges of oxytocin after noradrenaline infusions on days 15 and 16 did not cause any significant changes in concentrations of PGFM in plasma (below the sensitivity of assay) in any of the heifers. The time of luteolysis, as measured by a fall in progesterone concentration below $2 \mathrm{ng} \mathrm{ml}^{-1}$ (Roche et al., 1981; Kotwica and Williams, 1982), was very similar in heifers treated with noradrenaline on days 11,12 and 15,16 and (17.6 \pm 0.7 and $18.0 \pm 0.5$ days, respectively) compared with controls (18.0 \pm 0.3 days) (Table 2 ).

\section{Discussion}

Results from Expt $I$ indicate that although noradrenaline stimulated the release of large amounts of ovarian oxytocin, the corpus luteum was not completely depleted of this peptide. Subsequent infusions of noradrenaline also released oxytocin, but the amount decreased with each infusion $(P<0.05)$. Flint and Sheldrick (1983) found that PGF $_{2 \alpha}$ released approximately $98 \%$ of total oxytocin stored in the corpus luteum of ruminants. Kotwica et al. (1991a) showed that $\mathrm{PGF}_{2 a}$ given together with noradrenaline did not significantly increase oxytocin secretion. We assumed on that basis that noradrenaline $4 \mathrm{mg}$ given into the aorta abdominalis) caused a temporary but almost complete depletion of oxytocin from the corpus luteum. However, I h later the same dose of noradrenaline could release more oxytocin. This was apparently not a result of oxytocin synthesis, because Swann et al. (1984) showed that cysteine was incorporated into oxytocin precursor in bovine corpora lutea only after $12 \mathrm{~h}$ of incubation. Oxytocin secretion, after the 
Table 1. Percentage of oxytocin released (mean \pm SEM) from bovine corpora lutea by noradrenaline infusions on (a) days 11 and 12 of the oestrous cycle and by the $\mathrm{PGF}_{2 a}$ analogue given on day 12 after last noradrenaline treatment and amount of oxytocin released by $\mathrm{PGF}_{2 \alpha}$ only on day 12; (b) the same experimental design on days 15 and 16 of the oestrous cycle

\begin{tabular}{|c|c|c|c|c|c|c|}
\hline & & $\begin{array}{l}\text { Noradrenaline } \\
\text { infusions on day }\end{array}$ & & $\begin{array}{l}\mathrm{PGF}_{2 a} \\
\text { injection }\end{array}$ & $\begin{array}{l}\text { Total oxytocin } \\
\text { released }\end{array}$ & $\begin{array}{l}\text { Total oxytocin } \\
\text { released by } \text { PGF }_{2 a}\end{array}$ \\
\hline \multirow[t]{2}{*}{ (a) } & II & 12 & $11+12$ & & & \\
\hline & $42.5 \pm 1.4^{\mathrm{a}}$ & $31.2 \pm 1.1^{\mathrm{ab}}$ & $73.7 \pm 3.0^{c}$ & $26.3 \pm 3.0^{\mathrm{bd}}$ & $100(23.5 \pm 2.4)$ & $(23.4 \pm 2.0)$ \\
\hline \multirow[t]{2}{*}{ (b) } & 15 & 16 & $15+16$ & & & \\
\hline & $43.1 \pm 3.8^{\mathrm{a}}$ & $30.9 \pm 3.2^{\mathrm{ab}}$ & $74.0 \pm 1.3^{c}$ & $25.9 \pm 1.3^{\mathrm{bd}}$ & $100(15.3 \pm 1.4)$ & $(15.8 \pm 0.9)$ \\
\hline
\end{tabular}

Values in parentheses represent total area under the curve of oxytocin $(n=4)$.

${ }^{a b d} V$ alues with different superscripts are significantly different $(P<0.02)$.

${ }^{a b c d}$ Values with different superscripts are significantly different $(P<0.001)$.

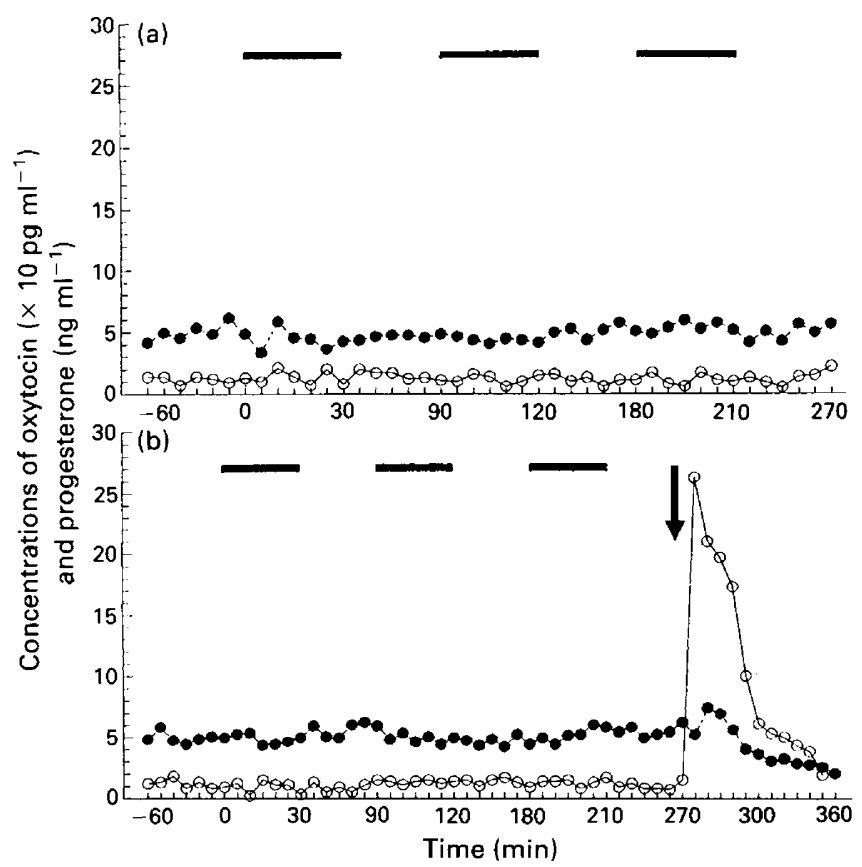

Fig. 2. Peripheral plasma concentrations of $(O)$ oxytocin and $(O)$ progesterone from one representative heifer infused with saline three times for $30 \mathrm{~min}(\longrightarrow$ ) on (a) day 11 and (b) day 12 and injected with $500 \mu \mathrm{g}$ of $\mathrm{PGF}_{2 \alpha}$ analogue (arrow) one hour after the last infusion on day 12 of the oestrous cycle.

initial noradrenaline infusion, may therefore represent posttranslational processing of the prohormone (Fehr et al., 1987) but not de novo synthesis. If this is true, it remains to be shown whether noradrenaline itself stimulates this process or whether other factor(s) dependent on noradrenaline can restore oxytocin in the corpus luteum.

Luck and Jungclas (1987) found that catecholamines stimulate oxytocin and progesterone secretion directly from granulosa cells. It should be noted that this effect was observed after many hours of incubation, whereas in the present study this effect of noradrenaline was obtained after $5 \mathrm{~min}$. Hence, it is assumed
Table 2. Mean $( \pm S E M)$ time at which the peripheral concentration of progesterone fell below $2 \mathrm{ng} \mathrm{ml}^{-1}$ and onset of oestrus in control heifers and in heifers infused with noradrenaline on days 11 and 12, and on days 15 and 16 of the oestrous cycle

\begin{tabular}{lccc}
\hline $\begin{array}{l}\text { Noradrenaline } \\
\text { infusion on days }\end{array}$ & $\begin{array}{c}\text { Number } \\
\text { of } \\
\text { heifers }\end{array}$ & $\begin{array}{c}\text { Time progesterone } \\
\text { concentration fell } \\
\text { below } 2 \mathrm{ng} \mathrm{m}^{-1} \text { (days) }\end{array}$ & $\begin{array}{c}\text { Onset of } \\
\text { oestrus } \\
\text { (days) }\end{array}$ \\
\hline 11,12 & 5 & $17.6 \pm 0.7$ & $20.8 \pm 0.6$ \\
15,16 & 6 & $18.0 \pm 0.5$ & $21.0 \pm 0.4$ \\
Control & 4 & $18.0 \pm 0.3$ & $21.0 \pm 0.5$ \\
\hline
\end{tabular}

that such a rapid response resulted not only from a direct influence on the luteal cells via $\beta$-receptors (Godkin et al., 1977; Luck and Jungclas, 1987; Kotwica et al., 1991b) but also of some other factors that amplified this effect indirectly. Blood vessels or myofibrils of smooth muscles could be involved (Reynolds and Ford, 1984). However, recent studies have revealed that blood pressure changes and $\alpha$-adrenoceptors are not involved in noradrenaline-stimulated oxytocin secretion (Skarzynski and Kotwica, 1993). The decreasing amount of oxytocin secreted after each noradrenaline infusion on the same day of the cycle could have been caused by a depletion of oxytocin stores in the luteal cells, or by the very short intervals between noradrenaline infusions which did not allow synthesis of oxytocin from its prohormone (Ivell, 1987). The lower amounts of oxytocin secreted on the second day of noradrenaline treatment (i.e. days 12 or 16 of the cycle compared with day 11 and 15 , respectively) suggest that the total amount of oxytocin synthesis in the luteal cells was markedly reduced. Data by Ivell et al. (1985) from days 5-7 of bovine oestrous cycle revealed that there is no de novo synthesis of oxytocin prohormone and hence it is not replenished once discharged. Each surge of oxytocin therefore decreased the total content in the corpus luteum.

Ovarian oxytocin may be involved in the regulation of steroidogenesis in the corpus luteum (Mares and Casida, 1963; 


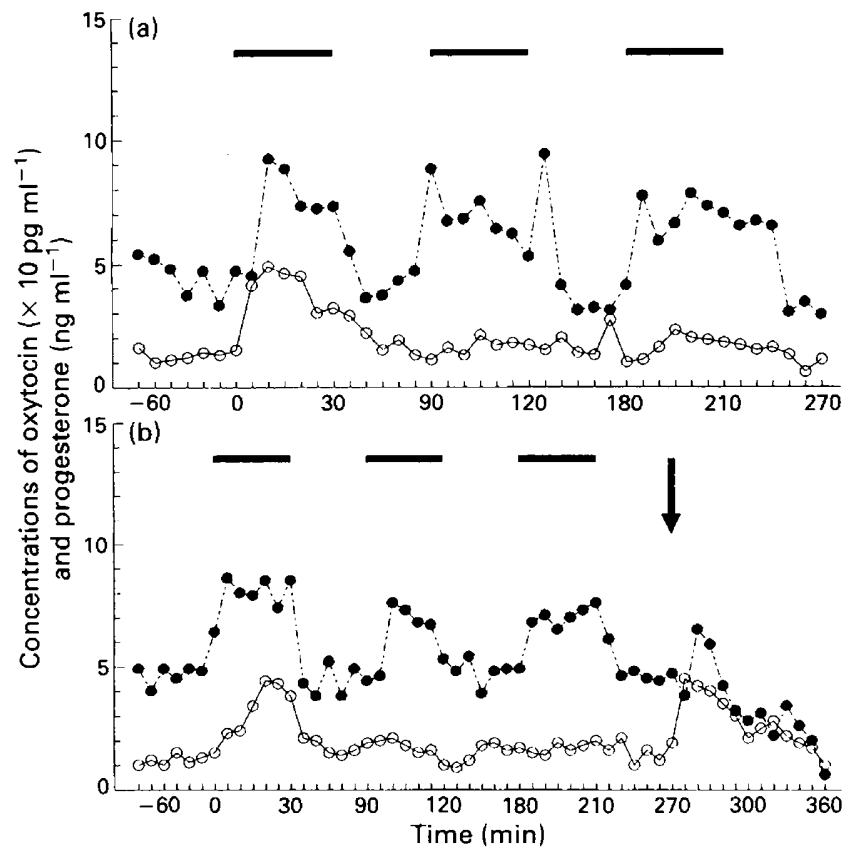

Fig. 3. Peripheral plasma concentrations of $(O)$ oxytocin and $(O)$ progesterone in a representative heifer infused with noradrenaline $(0.3 \mu \mathrm{g}$ $\mathrm{kg}^{-1} \mathrm{~min}^{-1}$ ) three times for $30 \mathrm{~min}$ ( $\longrightarrow$ ) on (a) day 15 and (b) day 16 and injected with $500 \mu \mathrm{g}$ of $\mathrm{PGF}_{2 \alpha}$ analogue (arrow) $1 \mathrm{~h}$ after last infusion of noradrenaline on day 16.

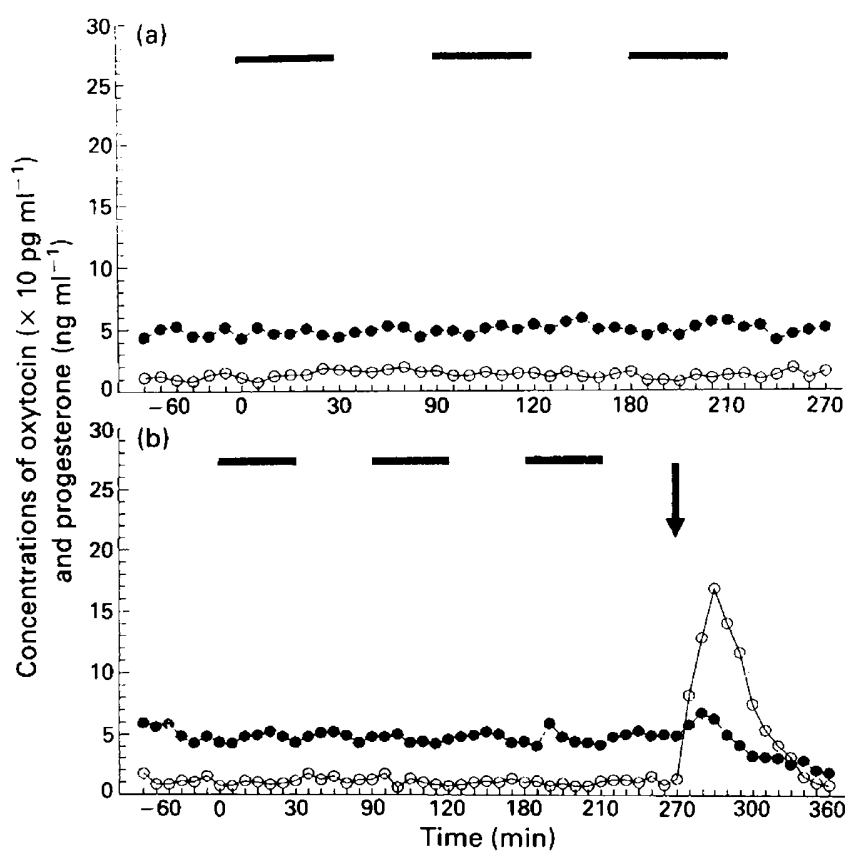

Fig. 4. Peripheral plasma concentrations of $(O)$ oxytocin and $(O)$ progesterone from one representative heifer infused with saline three times for $30 \mathrm{~min}$ (—) on (a) day 15 and (b) day 16 and injected with $500 \mu \mathrm{g}$ of $\mathrm{PGF}_{2 \alpha}$ analogue (arrow) $1 \mathrm{~h}$ after last infusion on day 16 of the oestrous cycle.
Tan et al., 1982). Concomitant secretion of oxytocin and progesterone in this experiment in the mid- but not late, luteal phase supports data obtained by Jarry et al. (1990) and Miyamoto and Schams (1991). It should be emphasized that the last study used corpora lutea microdialysis as an experimental model, and thus considered cell-to-cell communication and the autocrine and paracrine effects of oxytocin on corpus luteum function. Towards the end of the oestrous cycle, however, oxytocin and progesterone were not released concomitantly after noradrenaline infusion. This can be explained in two ways: (i) oxytocin acts locally (in the corpus luteum) and owing to the reduced amount there, it was not released into the general circulation or (ii) at this stage of the cycle oxytocin plays an opposite role. Flint et al. (1986) reported that, in sheep, oxytocin stimulates the phosphatidylinositol cycle in the endometrium, and the diacylglycerol formed is subsequently broken down to release arachidonic acid, a rate-limiting step precursor in the synthesis of prostaglandins (Irvine, 1982). Since bovine corpora lutea can also synthesize prostaglandins (Milvae, 1986; Hu et al., 1990), the same process may also occur. In both cases, some oxytocin should be present in corpora lutea. Data from Expts 2 and 4 indicate, however, that the removal of approximately $75 \%$ (range $68-82$ ) of oxytocin from the corpora lutea (Table 1 ) has no influence on the duration of the oestrous cycle (Table 2 ). It is therefore possible that the remaining oxytocin in the corpus luteum (approximately $25 \%$ ) may prevent any changes in function. It is unlikely, however, that such a small amount of oxytocin in the corpus luteum could initiate and support the pulsatile secretion of $\mathrm{PGF}_{2 \alpha^{\prime}}$ as suggested by McCracken et al. (1984). The treatment of cows with exogenous oxytocin to release uterine $\mathrm{PGF}_{2 \alpha}$ and to downregulate oxytocin receptors required up to $10-20$-fold excess of this hormone in the peripheral blood (Lafrance and Goff, 1988; Silvia and Taylor, 1989; Howard et al., 1990; Lutz et al., 1990) above physiological pulses at the time of luteolysis (Schams et al., 1985). Hence we assume that ovarian oxytocin acts mainly inside the ovary as an autocrine or paracrine hormone, or, alternatively, it is not crucial for luteolysis in cattle.

Luck and Jungclas (1987) using an in vitro system showed that propranolol blocks the stimulation of oxytocin secretion by adrenaline, but the stimulation of progesterone secretion was not affected. In contrast, Heap et al. (1989) found that in sheep, noradrenaline stimulated ovarian oxytocin secretion, but this was not accompanied by an increase of progesterone release. Specific membrane $\boldsymbol{\beta}$-receptors undergo downregulation if continuously activated by adrenomimetics (Davies and Lefkowitz, 1984; Aguado and Ojeda, 1984). However, as a constant response of progesterone to noradrenaline infusion was observed in this study, we assume that this was not the case and that the secretion of oxytocin and progesterone is governed by different mechanisms. Data by Hirst et al. (1986) and Luck (1988) support this view.

Lack of a response of oxytocin to $\mathrm{PGF}_{2 \alpha}$ on days 15 and 16 of the oestrous cycle is contrary to data obtained by Lafrance and Goff (1988) and Howard and Britt (1987). It should be emphasized, however, that they injected subcutaneously or intravenously up to 100 iu of oxytocin and this increased peripheral concentrations to $>2000 \mathrm{pg} \mathrm{ml}^{-1}$ of plasma. However, physiological pulses of oxytocin in the peripheral blood during luteolysis in cattle were in a range of $20-50 \mathrm{pg} \mathrm{ml}^{-1}$ (Schams 
et al., 1985), i.e. very close to the height of pulses obtained in the present studies. Moreover, a marked increase in the number of uterine oxytocin receptors was observed from day 17 to day 18 of the oestrous cycle (Meyer et al., 1988; Jenner et al., 1991). This may help to explain these discrepancies.

After noradrenaline infusion, a significant increase in progesterone secretion after $\mathrm{PGF}_{2 \alpha}$ injection was observed $(P<0.01)$ and positively correlated with the oxytocin surge $(r=0.73 ; P<0.001)$ contrary to the rise caused by $\mathrm{PGF}_{2 a}$ given after saline treatment (Figs $I$ to 4 ). This increase in progesterone release has been explained as an early degradation of the large luteal cells caused by $\mathrm{PGF}_{2 \alpha}$ (Heath et al., 1983). We can therefore assume that noradrenaline increased the sensitivity of large luteal cells to $\mathrm{PGF}_{2 \alpha}$. However, earlier noradrenaline infusions could also increase the total amount of progesterone stored in the corpus luteum.

In conclusion, noradrenaline infused into the aorta abdominalis markedly reduced oxytocin content of bovine corpora lutea during mid- and late-luteal phase but this did not affect the duration of the oestrous cycle. Surges of oxytocin $(20-60 \mathrm{pg}$ $\mathrm{ml}^{-1}$ ) provoked by noradrenaline on days 15-16 were similar to those released spontaneously during luteolysis but they could not stimulate PGF $_{2 \alpha}$ secretion. Hence we assume that if ovarian oxytocin is involved in the luteolysis in cattle it acts inside the ovary as an autocrine or paracrine hormone.

This study was supported by a grant from the Committee of Scientific Investigations (No. 66404 91 02). We thank G. D. Niswender (Colorado State University, Fort Collins, USA) for generously providing progesterone antiserum, G. Kotwica (University of Agriculture and Technology, Olsztyn) for oxytocin antiserum and W. J. Silvia (University of Kentucky, Lexington, USA) for anti-PGFM. We are indebted to S. Niedzwiedzki and B. Niedzwiedzka (Animal State Farm, Linowiec) for excellent cooperation.

\section{References}

Aguado LI and Ojeda SR (1984) Prepubertal ovarian function is finely regulated by direct adrenergic influences. Role of noradrenergic innervation Endocrinology 114 1845-1853

Davies AO and Lefkowitz RJ (1984) Regulation of $\beta$-adrenergic receptors by steroid hormones Annual Review of Physiology 46 119-130

Del Vecchio RP, Chase CC, Tibbitts FD and Randel RD (1991) Oxytocininduced prostaglandin release from perifused bovine caruncular and intercaruncular endometrial tissue on days 20,30 and at first estrus postpartum Prostaglandins 41 407-417

Fehr S, Ivell R, Koll R, Schams D, Fields M and Richter D (1987) Expression of the oxytocin gene in the large cells of the bovine corpus luteum FEBS Letters $21045-50$

Flint APF and Sheldrick EL (1982) Ovarian secretion of oxytocin is stimulated by prostaglandin Nature $297587-588$

Flint APF and Sheldrick EL (1983) Secretion of oxytocin by the corpus luteum in sheep Progress in Brain Research 60 521-530

Flint APF and Sheldrick EL (1986) Ovarian oxytocin and maternal recognition of pregnancy Joumal of Reproduction and Fertility 76 831-839

Flint APF, Leat WMF, Sheldrick EL and Stewart HJ (1986) Stimulation of phosphoinositide hydrolysis by oxytocin and the mechanism by which oxytocin controls prostaglandin synthesis in the ovine endometrium Biochemical Journal $237797-805$

Fuchs AR (1988) Oxytocin and ovarian function Journal of Reproduction and Fertility Supplement 36 39-47

Gibori G, Antczak E and Rotchild I (1977) The role of oestrogen in the regulation of luteal progesterone secretion in the rat after day 12 of pregnancy Endocrinology 100 1483-1495
Godkin JD, Black DL and Duby RT (1977) Stimulation of cyclic AMP and progesterone synthesis by $\mathrm{LH}, \mathrm{PGE}_{2}$ and isoproterenol in the bovine $\mathrm{CL}$ in vitro Biology of Reproduction 17 514-518

Gross TS, Thatcher WW, Hansen PJ and Lacroix MC (1988) Prostaglandin secretion by perifused bovine endometrium: secretion toward myometrial and luminal sides at Day 17 post-estrus as altered by pregnancy Prostaglandins $\mathbf{3 5}$ 343-357

Heap RB, Fleet IR, Davis AJ, Goode JA, Hamon MH, Walters DE and Flint APF (1989) Neurotransmitters and lymphatic-vascular transfer of prostaglandin $F_{2}$ stimulate ovarian oxytocin output in sheep Joumal of Endocrinology $\mathbf{1 2 2}$ 147-159

Heath E, Weinstein P, Merritt B, Shanks R and Hixon J (1983) Effects of prostaglandins on the bovine corpus luteum: granules, lipid inclusions and progesterone secretion Biology of Reproduction 29 977-985

Hirst JI, Rice GE, Jenkin G and Thorburn GD (1986) Secretion of oxytocin and progesterone by ovine corpora lutea in vitro Biology of Reproduction 35 1106-1114

Homanics GE and Silvia WJ (1988) Effects of progesterone and estradiol-17 $\beta$ on uterine secretion of prostaglandin $F_{2}$ in response to oxytocin in ovariectomized ewes Biology of Reproduction 38 804-811

Howard HJ and Britt JH (1987) Prostaglandin F metabolite after exogenous oxytocin in cows given hCG during diestrus Biology of Reproduction 36274

Howard HJ, Morbeck DE and Britt JH (1990) Extension of oestrous cycles and prolonged secretion of progesterone in non-pregnant cattle infused continuously with oxytocin Journal of Reproduction and Fertility 90 493-502

Hu Y, Sanders JHD, Kurz SG, Ottobre JS and Day ML (1990) In vitro prostaglandin production by bovine corpora lutea destined to be normal or short-lived Biology of Reproduction 42 801-807

Irvine RF (1982) How is the level of free arachidonic acid controlled in mammalian cells Biochemical Joumal 204 3-16

Ivell R (1987) Vasopressinergic and oxytocinergic cells: models in neuropeptide gene expression. In Neuropeptides and their Peptidases pp 3I-64 Ed. WH Turner. Ellis Horwood Ltd, Chichester, England and VCH, Weinheim, Germany

Ivell R, Brackett KH, Fields MJ and Richter D (1985) Ovulation triggers oxytocin gene expression in the bovine ovary FEBS Letters 190 263-267

Jarry J, Einspanier A, Kangießner L, Dietrich M, Holtz W and Wuttke W (1990) Release and effects of oxytocin on estradiol and progesterone secretion in porcine corpora lutea as measured by an in vivo microdialysis system Endocrinology 126 2350-2358

Jenner LJ, Parkinson TJ and Lamming GE (1991) Uterine oxytocin receptors in cyclic and pregnant cows Journal of Reproduction and Fertility 91 49-58

Kotwica J and Williams GL (1982) Relationship of plasma testosterone concentrations to pituitary-ovarian hormone secretion during the bovine estrous cycle and the effects of testosterone propionate administered during luteal regression Biology of Reproduction 27 790-801

Kotwica J, Schams D and Meyer HHD (1987) Effect of oxytocin on PGF $_{2 a}$ release by bovine and sheep endometrium Joumal of Endocrinology 112 Supplement Abstract 53

Kotwica J, Skarzynski D and Jaroszewski J (1990) Coccygeal artery as a route for the administration of drugs into the reproductive tract of cattle Veterinary Record 127 38-40

Kotwica J, Skarzynski D, Jaroszewski J and Kotwica G (1991a) Effect of norepinefrine on the release of progesterone and ovarian oxytocin in cattle Animal Reproduction Science 26 179-191

Kotwica J, Skarzynski D and Jaroszewski J (1991b) Involvement of $\beta$ adrenoceptors in the regulation of luteal function in cattle British Veterinary Journal 147 189-196

Lafrance M and Goff AK (1988) Effects of progesterone and oestradiol-17 $\beta$ on oxytocin-induced release of prostaglandin $\mathrm{F}$ in heifers Joumal of Reproduction and Fertility 82 429-436

Lafrance $M$ and Goff AK (1990) Control of bovine uterine prostaglandin $F_{2 a}$ release in vitro Biology of Reproduction 42 288-293

Luck M (1988) Ovarian oxytocin and progesterone are secreted independently of one another Molecular and Cellular Endocrinology 56 149-155

Luck M and Jungclas B (1987) Catecholamines and ascorbic acid as stimulators of bovine ovarian oxytocin secretion Journal of Endocrinology 114 423-430

Lutz SL, Smith MF, Keisler DH and Garverick HA (1990) Constant infusion of oxytocin extends luteal lifespan in heifers Journal of Animal Science 68 Supplement I 454-455

McCracken JA, Schramm W and Okulicz WC (1984) Hormone receptor control of pulsatile secretion of $\mathrm{PGF}_{2 a}$ from the ovine uterus during luteolysis and its abrogation in early pregnancy Animal Reproduction Science 7 31-55 
Mares SE and Casida LE (1963) Effect of exogenous oxytocin on the progestogen content of the bovine corpus luteum Endocrinology 72 78-82

Meyer HHD, Mittermeier Th and Schrams D (1988) Dynamics of oxytocin, estrogen and progestin receptors in the bovine endometrium during the estrous cycle Acta Endocrinologica 118 96-104

Meyer HHD, Enzenhofer G and Feck H (1989) Improvement of radioimmunoassays for prostaglandins in bovine blood plasma and their application to monitor reproductive functions Theriogenology 31 701-720

Milvae RA (1986) Role of luteal prostaglandins in the control of bovine corpus luteum function Journal of Animal Science 62 Supplement 2 72-78

Miyamoto A and Schams D (1991) Oxytocin stimulates progesterone release from microdialysed bovine corpus luteum in vitro Endocrinology 44 1163-1170

Pickering BT, Ayad VJ, Birkett SD, Gilbert CL, Guldenaar SEF, Nicholson HD Worley RTS and Wathes DC (1990) Neurohypophysial peptides in the gonads: are they real and do they have a function? Reproduction Fertility Development 2 245-262

Reynolds LP and Ford SP (1984) Contractility of the ovarian vascular bed during the oestrous cycle and early pregnancy in gilts Joumal of Reproduction and Fertility 71 65-71

Roche JF, Ireland J and Mawhinney S (1981) Control and induction of ovulation in cattle Journal of Reproduction and Fertility Supplement $30211-222$

Schams D, Schmidt-Polex B and Kruse V (1979) Oxytocin determination by radioimmunoassay in cattle Acta Endocrinologica 92 258-270
Schams D, Schallenberger E, Meyer HHD, Bullermann B, Breitinger H-J, Enzenhofer G, Koll R, Kruip TAM, Walters DL and Karg H (1985) Ovarian oxytocin during estrous cycle in cattle. In Oxytocin, Clinical and Laboratory Studies pp 317-334 Eds JA Amico and AG Robinson. Elsevier Biomedical, Amsterdam

Silvia WJ and Taylor ML (1989) Relationship between uterine secretion of prostaglandin $F_{2 a}$ induced by oxytocin and endogenous concentrations of estradiol and progesterone at three stages of the bovine estrous cycle Journal of Animal Science 67 2347-2353

Skarzynski D and Kotwica J (1993) Mechanism of noradrenaline influence on the secretion of ovarian oxytocin and progesterone in conscious cattle Journal of Reproduction and Fertility 97 419-424

Swann RW, O'Shaughnessy PJ, Birkett SD, Wathes DC, Porter DG and Pickering PT (1984) Biosynthesis of oxytocin in the corpus luteum FEBS Letters 173 262-266

Tan GJS, Tweedale R and Biggs JSG (1982) Effects of oxytocin on the bovine corpus luteum of early pregnancy Journal of Reproduction and Fertility 66 $75-78$

Wathes DC, Swann RW and Pickering BT (1984) Variation in oxytocin, vasopressin and neurophysin concentrations in the bovine ovary during the oestrous cycle and pregnancy Joumal of Reproduction and Fertility $71551-557$ 